\title{
Effect of organic nitrogen enrichments on marine planktonic networks and heterotrophic bacterial potential
}

\author{
France Van Wambeke, Micheline A. Bianchi \\ Microbiologie Marine, CNRS, U.P. R. 223, Faculté des Sciences de Luminy, case 907, 70 route Léon-Lachamp,
} F-13288 Marseille cedex 9, France

\begin{abstract}
The relationship between mineralization of organic matter (in the form of amino acid supplements) and growth of primary producers was investigated in batch cultures. Ammonium mineralization by the entire heterotrophic system, i. e. bacteria and grazers, was twice as fast as by bacteria alone. In spite of the nitrogen remineralized by the heterotrophic system, the maximum number of algae produced was dependent only on the limiting nutrient (phosphorus). Densities of bacteria of the Vibrio group rapidly increased after the amino acid enrichment. These zymogenous bacteria did not prevent the autotrophic phase but only delayed it, showing also phosphorus regeneration. After grazing, the bacterial composition was dominated by a pseudomonad population specialized in utilization of fatty acids, alcohols and intermediary metabolism compounds. This population was associated with primary producers. Exoenzymatic potential of the bacteria was also investigated during the whole succession. Dissolved nitrogen (inorganic- $\mathrm{N}$, dissolved free amino acids- $\mathrm{N}$ ) and particulate nitrogen (algal- $N$, bacterial- $N$ ) were estimated at the beginning of the experiment and at the maximum algal biomass. These data suggested the occurrence of an unidentified form of nitrogen. But when the N/P ratio (for available nutrients) was close to the Redfield ratio, most of the DFAA-N eventually supported phytoplankton growth.
\end{abstract}

\section{INTRODUCTION}

Coastal areas of the oligotrophic Mediterranean Sea are locally subject to large organic and mineral inputs from large rivers like the Rhône. These enrichments lead to increased primary production and a chlorophyll biomass as high as $30 \mu \mathrm{g} \mathrm{l}^{-1}$ (Demarcq 1985). In such waters, the link between microheterotrophic processes, i.e. bacterial growth - micropredator grazing - mineralization (Fenchel 1982, Azam et al. 1983, Andersson et al. 1985, Goldman \& Caron 1985, Moloney et al. 1986, Probyn 1987) and regenerated primary production, is of primary importance (Ducklow 1984).

In the present work we simulated allochtonous nitrogen inputs into oligotrophic Mediterranean seawater. Mesocosms of 3501 (previously used by Van Wambeke \& Bianchi 1985a, b) were filled with seawater from the Gulf of Marseilles, pre-filtered in order to discard mesoplankton. These were enriched with inorganic $\left(\mathrm{NH}_{4}{ }^{+}\right)$and/or organic nitrogen (amino acids) in order to stimulate simultaneously heterotrophic and autotrophic processes. We attempted to follow nitrogen from DFAA (dissolved free amino acids) to phytoplankton.

As a consequence of both heterotrophic and autotrophic processes, the catabolic potential of bacterial assemblages will fluctuate (Fukami et al. 1981, 1985, Van Wambeke \& Bianchi 1985a, b). Bacterial strains were isolated and their catabolic potentials investigated, for each sequential step, i. e. beginning of the experiment (no bacterial or algal growth), highest bacterial biomass, lowest bacterial biomass (due to grazing pressure and concomitant with algal growth), and end of the experiment (after algal growth).

\section{MATERIALS AND METHODS}

Experimental system. Four batches of 350 l (C, A, A' and $P$ ) were filled with seawater screened through a $10 \mu \mathrm{m}$ cellulose cartridge filter. After $2 \mathrm{~d}$ of stabilization, Batches $\mathrm{A}$, its duplicate $\mathrm{A}^{\prime}$, and $\mathrm{P}$ were supplemented with $100 \mu \mathrm{g}$-at. $\mathrm{N}^{-1}$ of 12 different amino acids at $5 \mu \mathrm{M}$ each: glycine, alanine, valine, leucine, 
methionine, phenylalanine tryptophan, serine, glutamic acid, aspartic acid, arginine and lysine. Batch P was inoculated with a diatom Phaeodactylum tricornutum (Bohlin) culture as $5 \times 10^{5}$ algae $\mathrm{l}^{-1}$ (final concentration). Nutrient salts (35 $\mu \mathrm{g}$-at. $\mathrm{N}-\mathrm{NH}_{4} \mathrm{I}^{-1}, 10 \mu \mathrm{g}$-at. $\mathrm{P}_{-} \mathrm{PO}_{4}{ }^{2-} \mathrm{I}^{-1}$ and $20 \mu \mathrm{g}$-at. Si-silicate $\mathrm{l}^{-1}$ ) were also added to this batch in order to promote algal growth. The control batch $(\mathrm{C})$ received only the filtered seawater.

Batches were kept in open air for $10 \mathrm{~d}$ in June, and were continuously aerated by bubbling. Average temperature was $20{ }^{\circ} \mathrm{C}$. Sampling intervals varied between $1.5 \mathrm{~h}$ and $1 \mathrm{~d}$ according to the parameter and the growth phase of bacteria and algae. The experiment started at 10:00 h.

Biomass determinations. Samples for counting algae and bacteria were fixed with formalin (final concentration $2 \% \mathrm{v} / \mathrm{v}$ ), and stained with acridine orange (final concentration $0.01 \% \mathrm{w} / \mathrm{v}$ ) using $0.2 \mu \mathrm{m}$ Nuclepore filters (Hobbie et al. 1977). Bacteria were counted and sized by an image analysis system and epifluorescence microscopy (Van Wambeke 1988). Usually 100 cells were sized on each filter. To compute the cell volume from bacterial projected surface, bacteria were considered as cylinders with 2 hemispherical caps (average length/width ratio:2). Nitrogen content of bacterial cells was estimated from epifluorescence counts and average bacterial volume using $0.11 \mathrm{~g} \mathrm{Ncm}^{-3}$ (Lee \& Fuhrman 1987).

Particulate chlorophyll a was determined fluorometrically, after filtration of $250 \mathrm{ml}$ of sample onto Whatman GF/C filters. Nitrogen content of Phaeodactylum tricornutum was calculated by using a $10.5 \mathrm{~N} / \mathrm{chl}$ a weight ratio (Sciandra 1982).

Particulate nitrogen and carbon were measured on samples (100 to $500 \mathrm{ml}$ ) filtered onto precombusted Whatman GF/C glass fiber filters using a Perkin Elmer Analyser calibrated with acetanilide.

Standard methods were used for analysis of phosphate, nitrate, nitrite and ammonia (Strickland \& Parsons 1972).

Amino acid concentrations were determined using high pressure liquid chromatography (HPLC) and the method described by Mopper \& Lindroth (1982). Samples were filtered through $0.22 \mu \mathrm{m}$ pore filters (Sartorius cellulose acetate). Pre-column derivatization was performed with ortho-phthaldialdehyde (OPA). Amino acid-OPA derivatives were separated on a reverse phase column by a methanol gradient in $0.05 \mathrm{M}$ aqueous sodium acetate at $\mathrm{pH} 5.9$. We considered as DFAA, the sum of the 15 amino acids detected, i. e. asp, glu, ser, hist, gly + thr (co-eluted), arg, ala, tyr, meth, val, phe, leu, ile and lys.

Data analyses. Specific growth rates of bacteria were determined from linear regression analysis of plots of the natural $\log$ of cell count versus time during the exponential growth phase.

Excretion rate per bacterial cell was determined as

$$
E=\left(N_{f}-N_{0}\right)\left(B_{m} \Delta t\right)^{-1}
$$

where $\mathrm{N}_{\mathrm{o}}$ and $\mathrm{N}_{\mathrm{f}}\left(\mu \mathrm{g}\right.$-at. $\left.\mathrm{N} \mathrm{l}^{-1}\right)=\mathrm{NH}_{4}{ }^{+}$excreted, respectively, at the beginning and end of the exponential phase of bacterial growth during the time interval $\Delta t(h) ; B_{m}=$ average concentration of bacteria (cells $1^{-1}$ ) during $\Delta t$. The equation $\left(B_{f}-B_{o}\right)\left(\ln B_{f}-\ln B_{o}\right)^{-1}$ of Heinbokel (1978) was used to determine $B_{m}$, where $B_{0}$ and $B_{1}$ are bacterial numbers (cells $l^{-1}$ ) at the beginning and end respectively of $\Delta t$.

Qualitative study of bacterial strains. The viable heterotrophic microflora (unit: colony forming units, $\mathrm{CFU} \mathrm{m}{ }^{-1}$ ) was estimated from serial dilution of $1 \mathrm{ml}$ of sample in $9 \mathrm{ml}$ of sterile seawater, inoculated in duplicate on marine agar plates (Oppenheimer \& Zobell 1952).

For each selected sample, changes in the qualitative composition of heterotrophic communities were assessed by isolating at random 20 bacterial strains from plate counts containing around $150 \mathrm{CFU}$ (Bianchi \& Bianchi 1982).

Altogether 100 morphological, physiological, biochemical and nutritional features were used to describe each strain (Van Wambeke et al. 1984). Results were coded in binary form. The strains were compared and clustered using the $\mathrm{KHI}_{2}$ coefficient and variance analysis. Any cluster or isolate appearing under 0.045 of taxonomic distance was considered as a separate ecotype.

Diversity index of each sample was calculated by the equitability index, as previously described in Sohier \& Bianchi (1985).

Catabolic indices determined for exoenzyme production (EAI), amino acids (AAI), carbohydrates (CAI), fatty acids (FAI), alcohols (OAI) and organic acids of intermediary metabolism (KAI), used as carbon and energy sources, were established as previously described (Van Wambeke \& Bianchi 1985a)

\section{RESULTS}

\section{Particulate compartments}

In Batches $\mathrm{A}, \mathrm{A}^{\prime}$ and $\mathrm{P}$ bacterial growth began 10 to $15 \mathrm{~h}$ after dissolved organic matter enrichment. In these batches, bacterial numbers increased from 0.3 to about $6 \times 10^{6}$ bacteria $\mathrm{ml}^{-1}$ (Fig. 1a). Bacterial growth rates $(\mu)$ were $0.085,0.113$ and $0.116 \mathrm{~h}^{-1}$ for Batches $\mathrm{A}$, $A^{\prime}$ and $\mathrm{P}$, respectively In the control, bacterial densities reached only $1.4 \times 10^{6}$ cells $\mathrm{ml}^{-1}(\mu=0.05$ $\mathrm{h}^{-1}$ ). In the 3 enriched batches, this phase lasted only $24 \mathrm{~h}$ before a large drop in bacterial densities. 

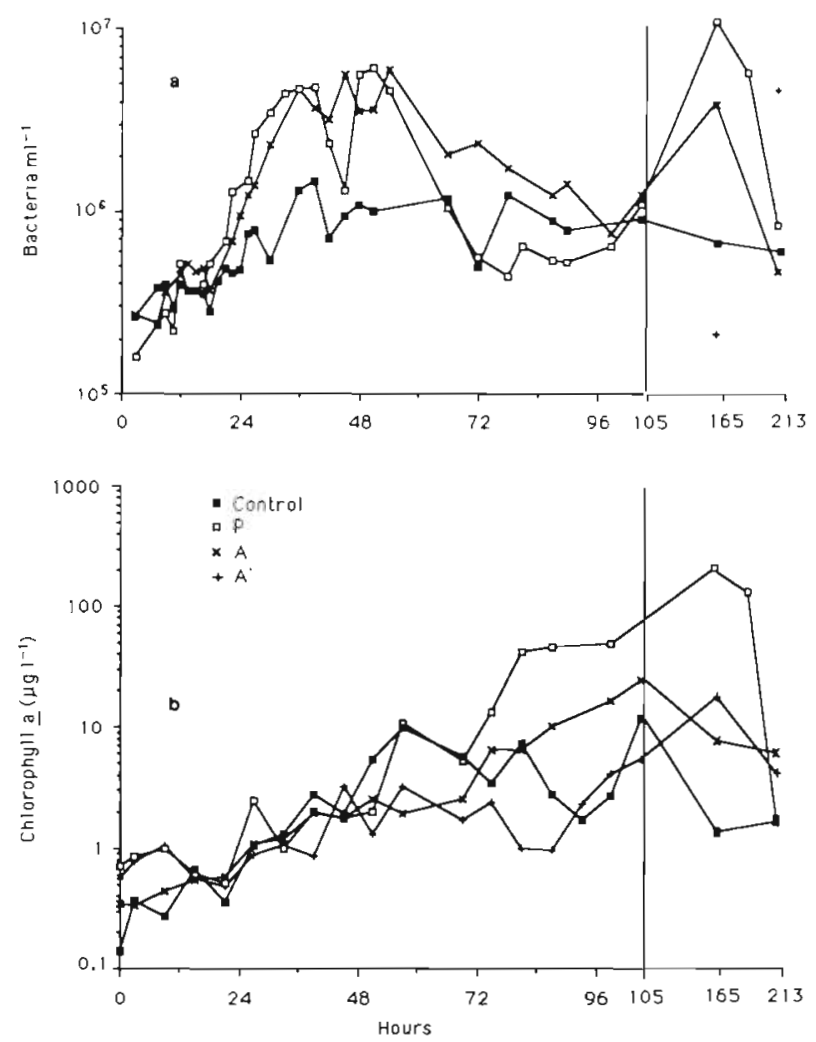

Fig. 1. (a) Bacterial acridine orange direct counts; (b) particulate chlorophyll $a$ in $(x)$ amino acids enriched Batches $A$ and (+) $\mathrm{A}^{\prime},(-)$ amino acid + Phaeodactylum tricornutum + nutrient enriched Batch $P$, and $(-)$ control $C$. Note the scale discontinuity at $105 \mathrm{~h}$. For clarity, bacterial counts in $\mathrm{A}^{\prime}$ were plotted only for the 2 last samples, all other values were close to that of $A$

Microflagellate grazing on bacteria occurred after $1.5 \mathrm{~d}$. These organisms were observed in bacterial acridine orange preparations, so they were counted only when their numbers peaked. The dominant species was a small, 4 to $5 \mu \mathrm{m}$ diameter, spherical microflagellate. Maximum values were about $3 \times 10^{4}$ $\mathrm{ml}^{-1}$. Predation decreased bacterial abundance to initial values in $18 \mathrm{~h}$.

Primary producers, as reflected by particulate chlorophyll a (chl a), grew in all batches (Fig. 1b). This algal production was due to Phaeodactylum tricornutum in Batch $\mathrm{P}$, in which this algae was inoculated, while in Batches $C, A$ and $A^{\prime}$, natural and diversified autotrophic microflora developed. In the control, chl a values increased simultaneously to those of the nutrient-replete batch (P) until $57 \mathrm{~h}$, when we measured $11.6 \mu \mathrm{g} \mathrm{chl} \mathrm{al}^{-1}$. In the control another peak $(9.8 \mu \mathrm{g} \mathrm{chl}$ $a^{-1}$ ) was seen at $105 \mathrm{~h}$. Maximum values of chl a appeared in the other batches at $105 \mathrm{~h}$ for $\mathrm{A}(24.4 \mu \mathrm{g}$ $\left.\mathrm{l}^{-1}\right)$, and $165 \mathrm{~h}$ for $\mathrm{A}^{\prime}\left(17.1 \mu \mathrm{g} \mathrm{l}^{-1}\right)$ and $\mathrm{P}\left(197 \mu \mathrm{gl}^{-1}\right)$. Afterwards, chl a decreased, concomitantly with a new increase in bacterial counts (at 165 and $213 \mathrm{~h}$ ).
During the microheterotrophic phase, until $70 \mathrm{~h}$, particulate nitrogen and bacterial nitrogen showed similar values in the 3 enriched batches (Fig. 2 a to d). Particulate nitrogen showed a marked increase (12 to $15, \mathrm{~kg}$-at. $\mathrm{N}$ 1 $^{-1}$, concomitant with bacterial growth. This increase, observed in the 3 amino acid enriched batches, was not parallelled by an increase in particulate carbon. During that period (21 to $33 \mathrm{~h}$; Table 1), $\mathrm{C} / \mathrm{N}$ ratios decreased from 7.9 to 5 . When phytoplankton growth occurred in Batch $\mathrm{P}$, particulate nitrogen increased markedly ( $71 \mu \mathrm{g}$-at. $\mathrm{N} \mathrm{I}^{-1}$ at $105 \mathrm{~h}$ ).
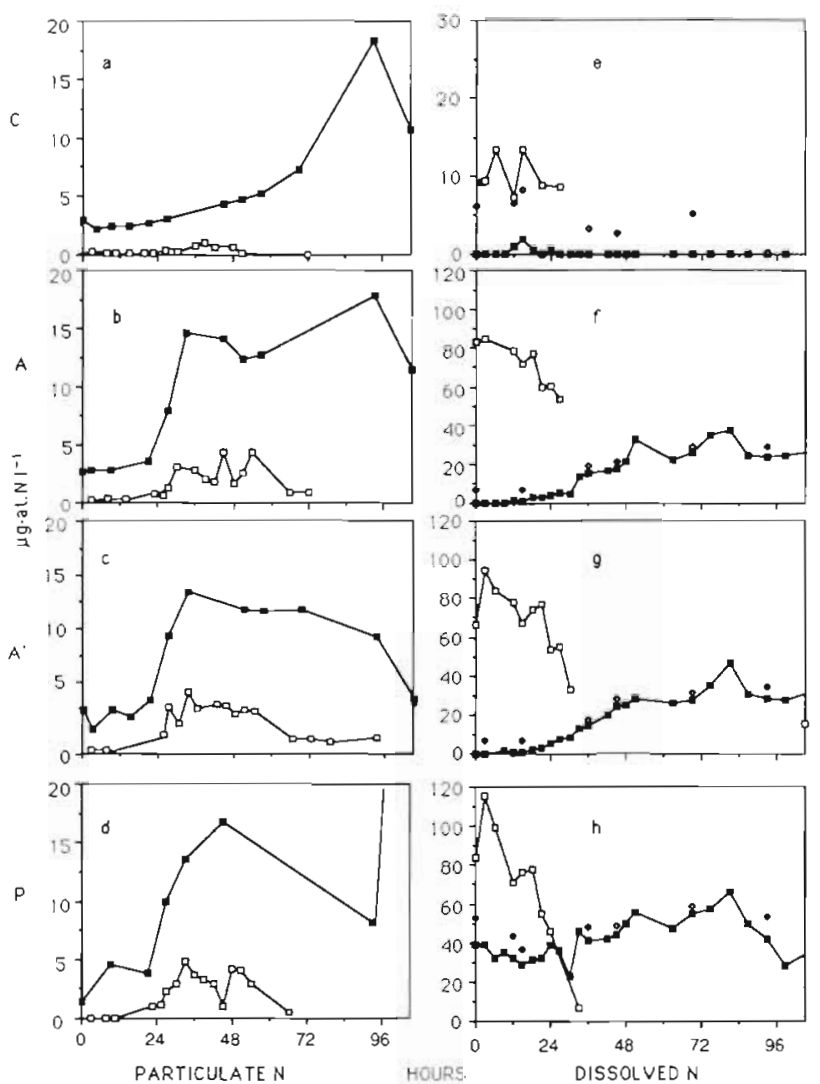

Fig. 2. (a to d) (-) Particulate nitrogen and (a) bacterial nitrogen; (e to h) (0) dissolved free amino acids nitrogen (DFAA-N), (-) $\mathrm{NH}_{4}^{+}$and $(\diamond)$ total dissolved inorganic nitrogen in $(a, e)$ control, amino acid enriched Batches (b, f) A and $(c, g) A$, and $(d, h)$ amino acid + Phaeodactylum tricornutum + nutrient enriched Batch $\mathrm{P}$

\section{Dissolved compounds}

In all batches total dissolved inorganic nitrogen concentrations (DIN) followed ammonium fluctuations, because oxidized forms $\left(\mathrm{NO}_{3}^{-}+\mathrm{NO}_{2}^{-}\right)$remained at 3 to $6 \mu \mathrm{g}$-at. $\mathrm{N}^{-1}$ during the whole experiment. In enriched batches, almost all (80\%) DFAA-N had disappeared by $36 \mathrm{~h}$ (Fig. $2 \mathrm{f}$ to h). Changes in $\mathrm{NH}_{4}^{+}$concentrations were similar in $A_{\text {and }} A^{\prime}$ (Fig. 2 f, g), as well as in Batch 
Table 1 Particulate matter $\mathrm{C} / \mathrm{N}$ ratios by (by atoms). Batches $A, A^{\prime}$ : amino acid enriched $\mathrm{P}$ : amino acid + Phaeodactylum tricornutum + nutrient enriched

\begin{tabular}{|ccccc|}
\hline Hour & Control & \multicolumn{3}{c}{ Batch } \\
& & A & A & P \\
\hline 0 & 11.85 & 12.6 & nd & 19.5 \\
3 & nd & 12.2 & 20.1 & nd \\
9 & 9.9 & 8.6 & 8 & 6 \\
15 & 10.3 & nd & 8.2 & nd \\
21 & 9.2 & 7.8 & 6.9 & 8.8 \\
27 & nd & 5.2 & 5 & 4.8 \\
33 & nd & 5 & 5.1 & 5.4 \\
45 & 4.4 & 4.4 & nd & nd \\
51 & 7.6 & 6.4 & 6.3 & nd \\
57 & 7.3 & 5.6 & 3.4 & nd \\
69 & 5.9 & nd & 5.3 & nd \\
93 & 6.1 & 5 & 5.1 & nd \\
99 & nd & nd & nd & nd \\
105 & 11.9 & 7.5 & 11.1 & 5.2 \\
165 & 5.7 & nd & nd & 5.5 \\
nd: not determined & & & \\
\hline
\end{tabular}

$\mathrm{P}$ when the concentration present at the beginning of bacterial growth (at $15 \mathrm{~h}$ ) was subtracted from subsequent values (Fig. 2 g). In the control (Fig. 2e), ammonium was undetected except at around $15 \mathrm{~h}$ (maximum value $8.2 \mu \mathrm{g}$-at. $\mathrm{N}^{-1}$ ).

Ammonium production versus time was exponential, and followed bacterial growth (Fig. 2 e to g). Most of the amino acid-nitrogen incorporated into bacteria was released through mineralization (Table 2). Net ammonium production was 22, 15 and $12 \%$ of the DFAA- $N$ decrease in Batches $A, A^{\prime}$ and $P$, respectively. This suggested a negligible flagellate excretion of $\mathrm{NH}_{4}^{+}$ during that period. Assuming no $\mathrm{NH}_{4}^{+}$excretion by flagellates, estimated bacterial excretion rates values were 3.1, 2.4 and 3.2 10 $0^{-10} \mu \mathrm{g}$-at. $\mathrm{N}-\mathrm{NH}_{4}^{+}$bacteria $^{-1}$ in Batches $A, A^{\prime}$ and $P$, respectively.

A new net ammonium increase was observed during a second phase (Fig. $2 \mathrm{f}$ to h) of bacterial predation by microflagellates. This phase occurred simultaneously in Batches $A, A^{\prime}$ and $P$ from 63 to $81 \mathrm{~h}$. If all bacterial nitrogen present was mineralized by the flagellate bac-
Table 3. Dissolved phosphate ( $\mu \mathrm{g}$-at. $\left.\mathrm{Pl}^{-1}\right)$ in the 4 batches. Batches A, A': amino acid enriched; P: amino acid + Phaeodactylum tricornutum + nutrient enriched

\begin{tabular}{|ccccc|}
\hline Hour & Control & \multicolumn{3}{c}{ Batch } \\
& & A & $\mathrm{A}^{\prime}$ & $\mathrm{P}$ \\
\hline 0 & 0.95 & 0.95 & 1.05 & 9.30 \\
12 & 0.85 & nd & nd & 8.30 \\
15 & 0.80 & 1.20 & 0.90 & nd \\
36 & 0.45 & 0.30 & 0.30 & 3.90 \\
45 & 0.47 & 0.45 & nd & 3.70 \\
69 & 0.40 & 0.27 & 0.35 & 3.85 \\
93 & 0.32 & 0.40 & 0.40 & 1.85 \\
165 & 0.23 & 0.55 & 0.30 & 1.15 \\
213 & 0.20 & 0.47 & 0.27 & 0.90 \\
nd: not determined & & & \\
\cline { 1 - 3 } & & & & \\
\hline
\end{tabular}

terivory - excretion processes (which is an extreme and unrealistic supposition), mineralization would be 9.2 , 8.6 and $10 \mu g$-at. $\mathrm{N}^{-1}$ in $\mathrm{A}, \mathrm{A}^{\prime}$ and $\mathrm{P}$, respectively. Since ammonia produced during that period was 15.7 . 20.7 and $18.8 \mu \mathrm{g}$-at. $\mathrm{N}^{-1}$ in these 3 batches, a continuous and significant $\mathrm{NH}_{4}^{+}$excretion by bacteria during DFAA catabolism, in the presence of bacterial predators, was thus demonstrated.

At the beginning of the experiment, there was $1 \mu \mathrm{g}$-at. $\mathrm{P}^{-1}$ in the control and amino acid enriched batches (Table 3). Over the whole experiment the $P$ concentration decreased to between 0.2 and $0.3 \mu \mathrm{g}$-at. $I^{-I}$ in these 3 batches. In Batch $P$ (nutrient salt enriched) the initial concentration was $9.2 \mu \mathrm{g}$-at. $\mathrm{Pl}^{-1}$ and decreased to close to $1 \mu \mathrm{g}$-at. $\mathrm{P}^{-1}$ after the phytoplankton growth.

\section{Changes in bacterial strains}

Bacterial strains were sampled during the 3 different phases observed in this experiment. Time $0 \mathrm{~h}$ corresponded to the beginning, $\mathrm{t} 36 \mathrm{~h}$ to the heterotrophic phase (maximum of bacterial viable counts), t $93 \mathrm{~h}$ to the phytoplankton growth phase and the minimum of viable counts, and $\mathrm{t} 213 \mathrm{~h}$ to the phytoplankton sta-

Table 2. Changes in dissolved, bacterial and phytoplankton nitrogen ( $\mu$ g-at. $\mathrm{N}^{-1}$ ) after $36 \mathrm{~h}$ of experiment: (a) calculated from changes in bacterial bjomass, $(b)$ assuming chl a/ $\mathrm{N}$ ratio $=10.5$. Batches, $\mathrm{A}_{1} \mathrm{~A}^{\mathrm{a}}:$ amino acid enriched; $\mathrm{P}$ : amino acids + Phaeodactylum tricornutum + nutrient enriched

\begin{tabular}{|cccccc|}
\hline Batch & $\begin{array}{c}\text { DFAA } \\
\text { decrease }\end{array}$ & $\begin{array}{c}\text { Bact. } N \\
\text { increase (a) }\end{array}$ & $\begin{array}{c}\text { Chl-N } \\
\text { increase (b) }\end{array}$ & $\begin{array}{c}\mathrm{NH}_{4}^{+} \\
\text {increase }\end{array}$ & $\begin{array}{c}\text { Particulate } \\
\text { Nincrease }\end{array}$ \\
A & 69.6 & 2.7 & 1.2 & 15.4 & 12.0 \\
A. & 79.8 & 3.5 & 0.4 & 14.6 & 12.7 \\
P & 109.0 & 3.6 & 1.4 & 0 & 14.4 \\
\hline
\end{tabular}


Table 4. Nutrient and biomass standing stocks for the sampling times selected for qualitative studies. (a) Situation of the determined parameter at the time of sampling considering surrounding values: max: value around the maximum, min: value around the minimum, dec: decrease, inc: increase. Batches $\mathrm{A}_{1} \mathrm{~A}^{\prime}$ : amino acid enriched; $\mathrm{P}$ : amino acid $+P$. tricornutum + nutrient enriched

\begin{tabular}{|c|c|c|c|c|c|c|c|}
\hline Batch & $\begin{array}{l}\text { Sampling } \\
\text { time } \\
\text { (h) }\end{array}$ & $\begin{array}{c}\text { Bacterial } \\
\text { total counts } \\
\left(10^{6} \mathrm{ml}^{-1}\right)\end{array}$ & $\begin{array}{c}\text { Total counts } \\
\text { curve pattern } \\
\text { (a) }\end{array}$ & 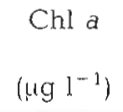 & $\begin{array}{c}\text { Chl a } \\
\text { curve pattern } \\
\text { (a) }\end{array}$ & $\begin{array}{c}\mathrm{NH}_{4}^{+} \\
\left(\mu \mathrm{g}-\mathrm{at} . \mathrm{Nl}^{-1}\right)\end{array}$ & $\begin{array}{c}\mathrm{PO}_{4}{ }^{-} \\
\left(\mu g-\text { at. } \mathrm{Pl}^{-1}\right)\end{array}$ \\
\hline \multirow[t]{4}{*}{ Control } & 0 & 0.26 & & 0.14 & & 0 & 1 \\
\hline & 36 & 1.46 & $\max$ & 2.75 & inc & 0 & 0.47 \\
\hline & 93 & 0.8 & & 1.71 & dec & 0 & 0.33 \\
\hline & 213 & 0.6 & & 1.54 & dec & 0 & 0.2 \\
\hline \multirow[t]{4}{*}{ A } & 0 & 0.27 & & 0.34 & & 0 & 1 \\
\hline & 36 & 3.64 & $\max$ & 1.95 & & 15.4 & 0.26 \\
\hline & 93 & 1 & $\min$ & 13.2 & inc & 23.8 & 0.38 \\
\hline & 213 & 0.47 & dec & 5.7 & dec & 28.7 & 0.46 \\
\hline \multirow[t]{4}{*}{$A$} & 0 & 0.2 & & 0.55 & & 0 & 1 \\
\hline & 36 & 5.1 & $\max$ & 0.84 & & 14.6 & 0.29 \\
\hline & 93 & 1.2 & $\min$ & 2.3 & inc & 28.3 & 0.4 \\
\hline & 213 & 4.3 & inc & 3.9 & dec & 26 & 0.31 \\
\hline \multirow[t]{4}{*}{$\mathrm{P}$} & 0 & 0.16 & & 0.71 & & 39.2 & 9.3 \\
\hline & 36 & 4.75 & $\max$ & 2 & & 41.65 & 3.6 \\
\hline & 93 & 0.55 & $\min$ & 47 & inc & 42.07 & 1.85 \\
\hline & 213 & 0.83 & dec & 1.6 & dec & 6 & 0.9 \\
\hline
\end{tabular}

tionary phase (control and A batches) or decomposition phase ( $\mathrm{P}$ and $\mathrm{A}^{\prime}$ batches). Nutrient and biomass standing stocks at these sampling times are summarized in Table 4. As all bacteria isolated were gram-negative, oxidase-positive, catalase-positive, non-pigmented rods, we distinguished mainly 2 bacterial groups: fermentative (Vibrio group), and non-fermentative (pseudomonad group).

Catabolic potentialities were different in the 4 batches at time 0 (Figs. 3 and 4 ), $P$ batch showing the highest nutritional indices and the lowest equitability index $(65 \%)$. But, at this time, in all batches, aerobic
Fig. 3. Diversity indexes and bacterial catabolic potentials in control (left) and amino acids + Phaeodactylum tricornutum + nutrient $\mathrm{P}$ (right) batches. Abcissa: time samples at $0,0 \mathrm{~h} ; 1,36 \mathrm{~h} ; 2,93 \mathrm{~h} ; 3$, $213 \mathrm{~h}$. See also Table 4 for details. All ordinate values are percentages, (a) Nutritional indices: amino acids (AAI), carbohydrates (CAI), alcohols (OAI), fatty acids (FAI) and organic acids of intermediary metabolism compounds (KAI) average utilization indexes. (b) Exoenzymes production percentage, reflected by abilities to hydrolyse extracellular phosphate, tween, starch, gelatin and DNA. (c) Percentage of isolated strains glucose fermentative and equitability index

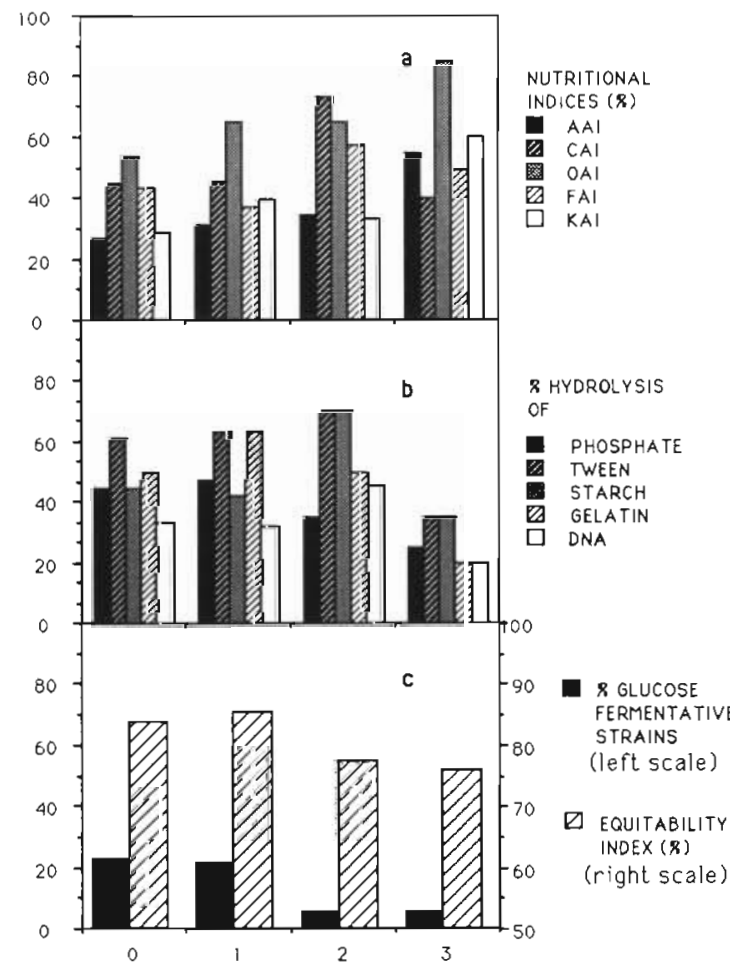

CONTROL BATCH

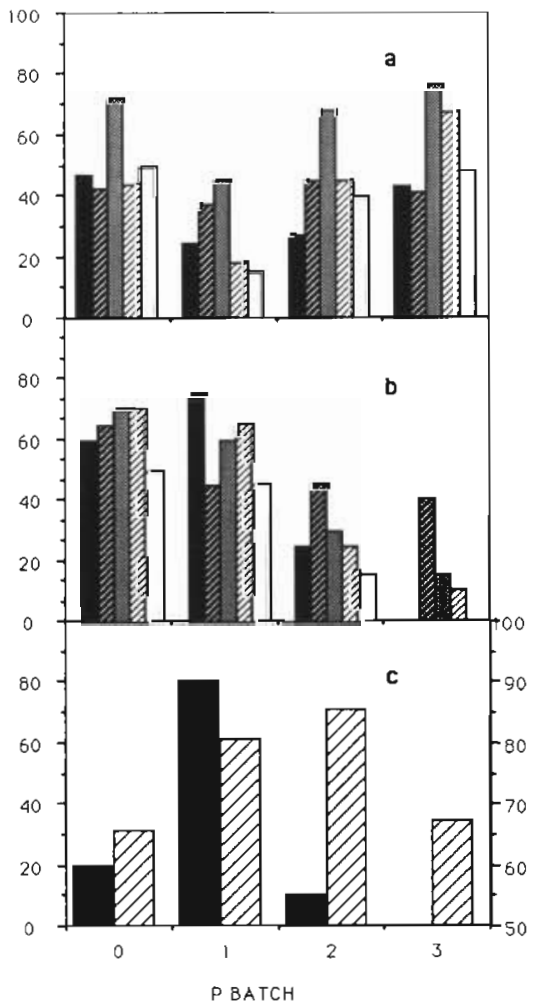




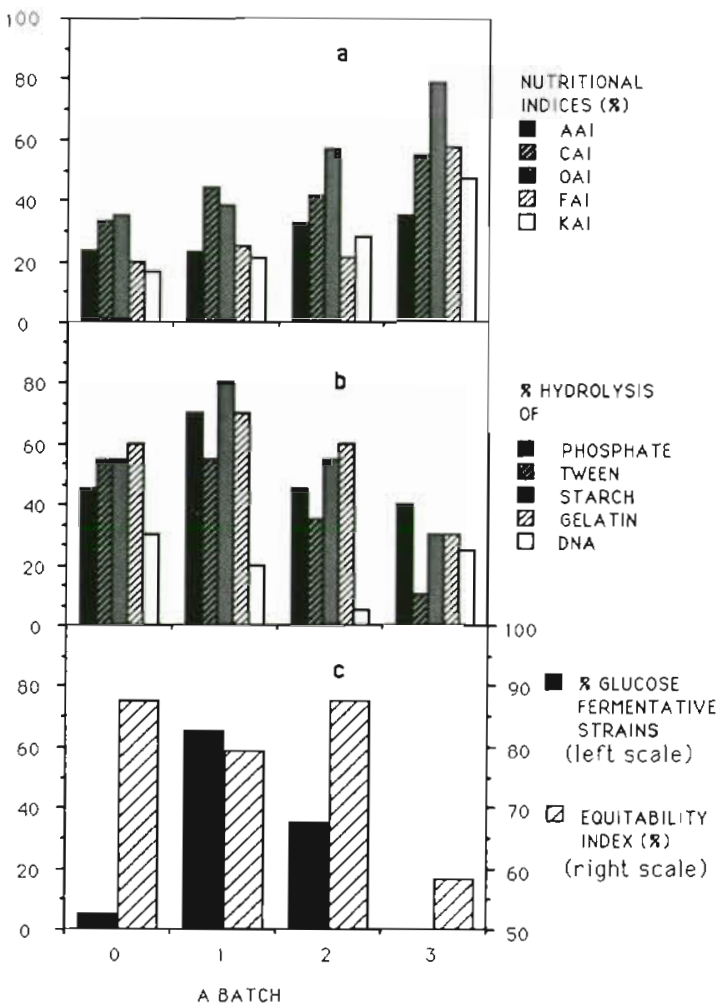

non-fermentative strains, belonging to the pseudomonad group, were dominant.

During the heterotrophic phase (36 h), corresponding to the maximum viable and total counts, the CFU/total counts ratio was $33 \%$ versus $1 \%$ just after enrichments. In Batches $\mathrm{A}, \mathrm{A}^{\prime}$ and $\mathrm{P}$, bacterial communities were dominated by the Vibrio group, as reflected by the high percentage of fermentative strains $(65,85$ and $80 \%$ in $A$. $A^{\prime}$ and $P$, respectively). In amino acid enriched batches, the decrease of equitability index values also demonstrated the dominance of a particular ecotype. The exoenzymatic potential activity (observed by hydrolysis of organic phosphate, tween 80, starch, gelatin and DNA; Figs. 3 and 4) remained high or even increased.

In spite of a large discrepancy between the nutritional versatility indices noted in Batches $A, A^{\prime}$ and $P$ at the beginning of the experiment, similar values were observed when they reached the highest counts. Alcohol $(\mathrm{OAI} \simeq 40 \%)$, fatty acid $(\mathrm{FAI} \simeq 20 \%)$, and intermediary metabolism acid ( $\mathrm{KAl} \simeq 20 \%$ ) average indices showed lower abilities to use simple organic compounds as sole carbon and energy source than at time 0 . This observation was confirmed for amino acids (reflected by AAI, around $25 \%$ ).

During the phytoplankton growth phase (93 h) and decomposition phase $(213 \mathrm{~h})$, hydrolysis potentials decreased. For example, $30 \%$ or less of the isolated strains possessed the ability to hydrolyse starch and gelatin in all batches at $213 \mathrm{~h}$, versus 50 to $80 \%$ at 36 and $93 \mathrm{~h}$.

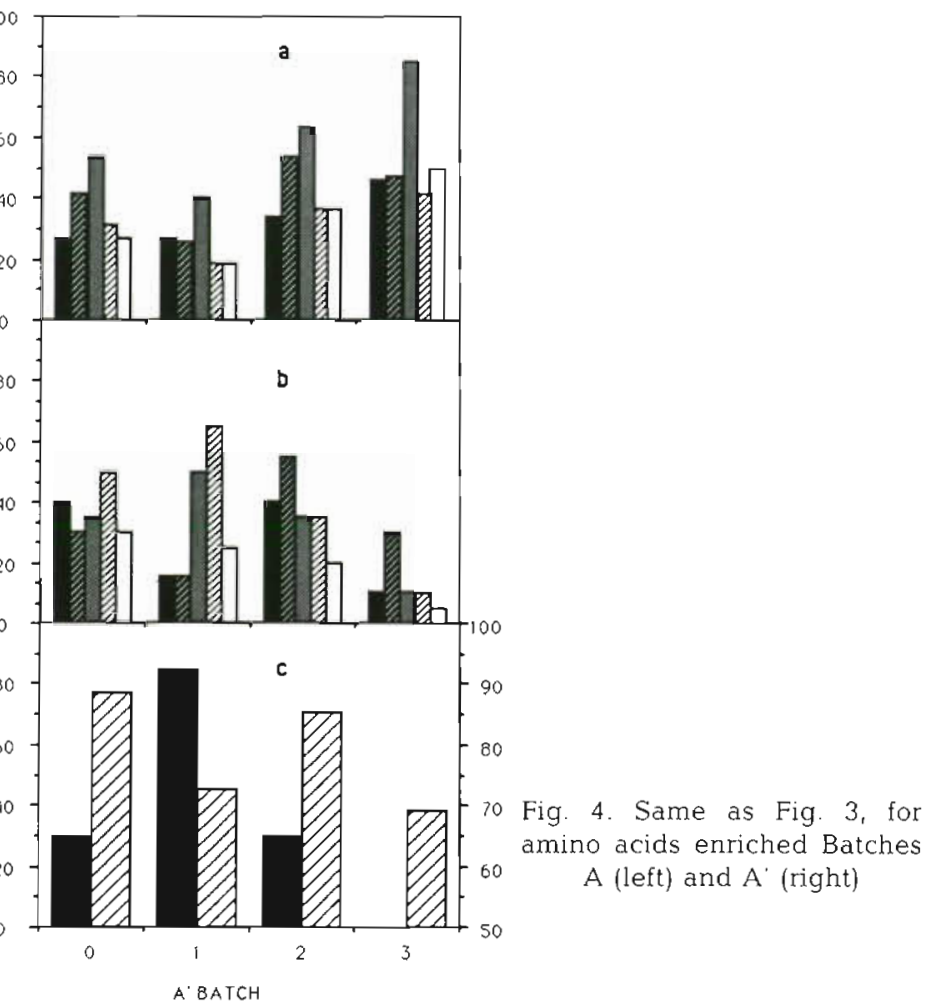

In contrast, all nutritional versatility indices increased greatly in the 4 batches during algal growth until Day 9. Values were higher than $75 \%$ for alcohols (OAI), 45\% for intermediary metabolism compounds (KAI) and $40 \%$ for fatty acids (FAI). At the end of the experiment, the pseudomonad group was again dominant

\section{DISCUSSION}

\section{Nitrogen budget}

In the closed microcosms we used, the dissolved organic nitrogen (DON) enrichment (amino acids) enhanced the activity of microheterotrophic organisms. The decrease of the particulate $\mathrm{C} / \mathrm{N}$ ratio value, as commonly observed in such eutrophication experiments (Fukami et al. 1981, Robinson et al. 1982, Van Wambeke \& Bianchi 1985b), demonstrated the heterotrophic production of cells. This heterotrophic phase corresponded to DON mineralization by bacteria and protozoa.

The $\mathrm{NH}_{4}^{+}$initial concentration did not affect heterotrophic bacterial activities. In the 3 enriched batches, despite the presence of $35 \mu \mathrm{g}$-at. $\mathrm{NH}_{4}^{+}-\mathrm{N} \mathrm{I}^{-1}$ in the $\mathrm{P}$ batch. (i) bacterial densities reached identical values; (ii) ammonium was regenerated at the same rate $(0.56$, 0.49 and $0.61 \mu g$-at. $\mathrm{NH}_{4}^{+}-\mathrm{N}^{-1} \mathrm{~h}^{-1}$ in Batches $\mathrm{A}_{1} \mathrm{~A}^{\prime}$ and $P$ respectively); (iii) no significant difference was noted in the amounts of $\mathrm{NH}_{4}^{+}$excreted. 


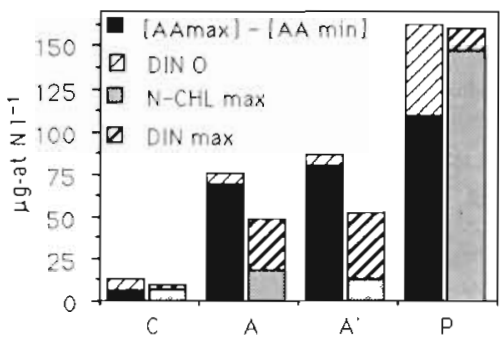

Fig. 5. Nitrogen budgets in Batches $C, A, A^{\prime}$ and $P$. Left bars: determined fraction of available nitrogen. [A.Amax]-[A.Amin]: difference between maximum and minimum concentrations observed in DFAA-N during the experiment; DIN 0: dissolved inorganic nitrogen present at $0 \mathrm{~h}$. Right bars: nitrogen status at the sampling time where maximum values of chl a were obtained, i.e. $57 \mathrm{~h}$ for $\mathrm{C}$ (control), $105 \mathrm{~h}$ for $\mathrm{A}, 165 \mathrm{~h}$ for $\mathrm{A}^{\prime}$ and P. DIN max, N-CHL max: dissolved inorganic nitrogen, and nitrogen equivalent of the chl a present at the chl a maximum sample, respectively

The nitrogen finally incorporated into phytoplankton depended on the N/P ratio and on the concentration of the limiting nutrient. In closed microcosms, because predators of the algae were screened out, the phytoplankton production can be directly related to chl a increases and potential phytoplankton production can be estimated from $\mathrm{N}$ and $\mathrm{P}$ initial stocks. The nitrogen budget (Fig. 5) shows that for the control and P batches, the sum: DFAA-N decrease + DIN (dissolved inorganic nitrogen) present at the beginning was equivalent to the sum: N-chl a increase + DIN present at the chl a peak. These results suggest that most of the DFA.A nitrogen pool was eventually utilised in phytoplankton growth, whatever the intermediary nitrogen compartments (DON, bacterial, protozoan, other particulate, DIN).

In amino acid enriched batches, the rapid microbial ammonium regeneration led to a change from nitrogen to phosphorus limitation. The maximum chl a value, obtained in Batches $A$ and $A^{\prime}$, was about $20 \mu \mathrm{g} \mathrm{I}^{-1}$. This value corresponds to theoretical phosphorus needs of about $0.5 \mu \mathrm{g}$-at. $\mathrm{P}^{-1}$, based on the average $\mathrm{N} / \mathrm{P}$ ratio of 30 by atoms (Goldman et al. 1987). Assuming a bacterial phosphorus cell quota of $0.006 \mathrm{pg} P$ (Andersen et al. 1986), the number of bacteria produced during the heterotrophic phase was equivalent to about $1 \mu \mathrm{g}$-at. bacterial organic phosphorus $1^{-1}$. This value corresponded to the dissolved phosphate present at the beginning of the experiment, demonstrating a rapid turnover of phosphorus. Such a rapidly adjusting mechanism of nutrient recycling by microheterotrophic activities was invoked by Lancelot \& Billen (1984) for nitrogen needs of phytoplankton during a spring bloom.

Because of $P$ limitation in Batches $A$ and $A^{\prime}$, the decrease in the N-DFAA pool was recovered neither in the phytoplankton compartment, nor in the DIN com- partment (Fig. 5). Distribution into other particulate compartments was excluded because nitrogen equivalents in bacteria or protozoa are negligible as compared to phytoplankton nitrogen in microplanktonic succession models in the euphotic zone (Newell et al. 1988). Goldman et al. $(1985,1987)$ found losses of nitrogen of about $25 \% \mathrm{~N}$ in P-limited diatom cultures. These authors suggested that the incomplete $N$ recovery was explained by bacterially-mediated aggregation and wall growth of algal cells. Values corresponding to the observed nitrogen losses $\left(28 \mu \mathrm{g}\right.$-at. $\mathrm{N}^{-1}$ for Batch A and $35 \mu \mathrm{g}$-at. $\mathrm{N}^{-1}$ for $\mathrm{A}^{\prime}$ ), if assigned to fixed phytoplankton production, and using the N/P ratio cited by Goldman et al. (1987) for P-limited cells, would imply that more than $1 \mu \mathrm{g}$-at. $\mathrm{P}^{-1}$ was consumed. Thus the phosphorus available in our system at the beginning of the experiment could not support production of both free and adhering algal cells.

The large loss of total $N$ could be due to an undetermined DON fraction. This might include dissolved combined amino acids (DCAA: peptides, polypeptides, proteins), urea, purines and pyrimidines, and also amino-sugar complexes (Flynn \& Butler 1986). DFAA, DCAA and urea constitute labile DON which is easily identified and measured, but constitutes only 5 to $20 \%$ of the total DON normally present in seawater (Billen 1984, Jackson \& Williams 1985). In the 3 amino acid enriched batches, at the end of the microheterotrophic phase, the increases in $\mathrm{N}$-bacteria plus $\mathrm{N}$-chl a were not able to balance the observed particulate nitrogen increase (Table 2). We presume that some of the $\mathrm{N}$ increase observed on these filters during bacterial growth was due to these undetermined nitrogen compounds, by absorption onto particles, and/or by formation of nitrogen-rich colloids aggregated with bacterialprotozoan complexes (Biddanda \& Pomeroy 1988).

In any case, this loss of nitrogen is reversible when the N/P ratio is close to the Redfield ratio, as we observed in the $\mathrm{P}$ and control batches (Fig. 5). Here the (N-CHL $\mathrm{Nax}_{\text {max }}+\mathrm{DIN}_{\max }$ ) corresponded to the available nitrogen we were able to determine (DFAA + DIN).

\section{Heterotrophic bacterial potential}

In the control, heterotrophic bacteria sustained high levels of catabolic potential and of taxonomic diversity during the entire experiment. Even so, FAI and OAI indices increased faster in the control batch than in the other batches, as observed at 36 h (Figs. 3 and 4). The equitability index did not fluctuate and the percentage of glucose fermentative strains did not increase at $36 \mathrm{~h}$ (Fig. 3). This suggested that these bacteria of diversified taxonomic origin, by possessing highly versatile enzymatic and transport systems, were able to grow at 
the expense of any organic compound present in the environment.

In amino acid enriched batches, amino acid average indices were minimum during the bacterial growth phase (heterotrophic phase) when the main organic carbon sources were only DFAA (Figs. 3 and 4). In extreme eutrophication conditions, corresponding to high concentrations of DFAAs (mostly glycine and ornithine), Rault et al. (1988) observed a similar lack of amino acid utilization as sole source of carbon and energy. Their strains required amino acids as growth factors which were not added to nutritional test media. However, in our case, at $36 \mathrm{~h}$, amino acid utilization indices were low and only $10 \%$ of the isolated strains required amino acids as growth factors.

On the other hand, in our batches, zooplankton were excluded, implying the importance of the sloppy-feeding process as a source of macromolecules to be low in the autotrophic phase. Consequently, during algal exponential growth the main sources of substrates available for exoenzyme hydrolysed were compounds actively released by algae, i. e. out of the inhibitory zone of healthy growing phytoplankton cells (Azam \& Ammermann 1984). It was shown (Eberlein \& Brockmann 1986, Bratbak 1987) that most peptides and polysaccharides are released after the expotential growth phase. Nevertheless, in our enriched batches, maximum exoenzymatic potential were observed during the phytoplankton exponential growth phase, and when the phytoplankton stationary phase and decomposition occurred, exoenzymatic hydrolysis potentials of bacterial communities decreased unexpectediy. However, for exoenzyme production, as for all other tests, no attempt was made to make quantitative estimates, either on isolated strains or in the original microcosms. A similar small exoenzyme production ability, in spite of the accurnulation of phytoplanktonic dead cells, was previously noted (Van Wambeke \& Bianchi 1985a).

In fact, in eutrophicated environments, organic substrates are not limiting and fast-growing bacteria, possessing high $V_{\max }$ values, compete successfully. They do not need diversıfıed nutritional potentials. Growing bacteria are opportunistic, ( $r$ strategy, zymogenous bacteria) as reflected by both high growth rates and high ammonium regeneration rates. Vibrio species are well-known to demonstrate such characteristics. The dominance of the Vibrio group observed in amino acid enriched batches was brief and did not influence a further succession of the non-fermentative, pseudomonad group, mostly specialized in utilization of fatty acids, alcohols and intermediary metabolism compounds (Figs. 3 and 4). Hammer \& Kattner (1986), studying DFAA C/N ratio shifts during diatom blooms, observed 'finger prints' of phytoplankton through specific patterns of organic compounds distributed over the water column. By analogy, the strain composition of heterotrophic bacteria could fit the 'finger print' given by primary producers.

In conclusion, the enrichment of dissolved organic matter induced a rapid production of zymogenous bacteria. In such a eutrophicated situation, the nature of bacterial heterotrophic potentials does not play a major role in their selection processes. Predation by microflagellates had a feedback role, regulating this population in only $24 \mathrm{~h}$. During that period, both vibrios and flagellates played an important role in mineralization of dissolved organic matter. When present, the phytoplanktonic cells induced a change in the qualitative composition of bacterial population, demonstrated by the increase of pseudomonads.

An unidentified form of nitrogen was produced during bacterial growth, part of which was detected on Whatman GF/C filters, suggesting the occurrence of colloid nitrogen complexes. But most of the DFAA-N was finally devoted to phytoplankton growth in Batch $P$ showing that this unidentified nitrogen form was not lost from the system when nitrogen and phosphorus sources are balanced.

Acknowledgements. This research was supported by EEC grant ENV-802 F. We are grateful to Dr D. Kirchman and an anonymous referee for their constructive comments throughout successive versions of the manuscript. We also thank $R$. Chiri, J. Garcin, J. P. Torreton and L. Sohier for their technical assistance during sampling procedures.

\section{LITERATURE CITED}

Andersen, O. K., Goldman, J. C., Caron, D. A., Dennett, M. R. (1986). Nutrient cycling in a microflagellate food chain: III. Phosphorus dynamics. Mar. Ecol Prog. Ser. 37: 47-55

Andersson, A., Lee, C., Azam, F., Hagström, A. (1985). Release of amino acids and inorganic nutrients by heterotrophic marine microflagellates. Mar. Ecol. Prog. Ser 23: 99-106

Azam, F., Ammermann, J W. (1984). Cycling of organic matter by bacterioplankton in pelagic marine ecosystems: microenvironmental considerations. In. Fasham, J. R. (ed.) Flows of energy and material in marine ecosystems. Theory and practice. NATO conference series, Plenum Press, New York, p. 345-360

Azam, F., Fenchel, T., Field, J. G., Gray, J. S., Meyer-Reil, L.-A., Thingstad, F. (1983). The ecological role of water-column microbes in the sea. Mar Ecol. Prog. Ser. 10: 257-263

Bianchi, M. A., Bianchi, A. J. (1982). Statistical sampling of bacterial strains and its use in bacterial diversity measurements. Microb. Ecol. 8: 61-69

Biddanda, B. A., Pomeroy, L. R. (1988). Microbial aggregation and degradation of phytoplankton-derived detritus in sea water. I. Microbial succesion. Mar. Ecol. Prog. Ser 42: $79-88$

Billen, G. (1984). Heterotrophic utilization and regeneration of nutrogen. In: Hobbie, J. E., Williams, P. J. le B. (eds.) Heterotrophic activity in the sea Plenum Press, N. Y., p. 313-355. 
Bratbak, G. (1987). Carbon flow in an experimental microbial ecosystem. Mar. Ecol. Prog. Ser 36: 267-276

Demarcq, H. (1985). Applications de la télédétection infrarouge et visible en océanographie. Etude de la zone de dilution Rhodanienne, observation des zones de production dans le golfe du Lion et estimation de l'éclairement solaire global en Méditerranée Occidentale. Thèse 3ème cycle, Océanologie, Univ. Aix-Marseille II

Ducklow, H. W (1984). Geographical ecology of marine bacteria: physical and biological variability at the mesoscale. In: Klung, M. J., Reddy, C. A. (eds.) Current perspectives in microbial ecology. American Society for Microbiology, Washington, D.C. p. 22-31

Eberlein, K., Brockmann, U. H. (1986). Development of particulate and dissolved carbohydrates in parallel enclosure experiments with monocultures of Thalassiosira rotula. Mar. Ecol. Prog. Ser. 32: 133-138

Fenchel, T (1982). Ecology of heterotrophic microflagellates. IV Quantitative occurrence and importance as bacterial consumers. Mar. Ecol. Prog. Ser. 9: 35-42

Flynn, K. J., Butler, I. (1986). Nitrogen sources for the growth of marine microalgae: role of dissolved free amino acids. Mar. Ecol. Prog. Ser. 34: 281-304

Fukami, K., Simidu, U., Taga, N. (1981). Fluctuation of the communities of heterotrophic bacteria during the decomposition process of phytoplankton. J. exp. Mar Biol. Ecol. 55: $171-184$

Fukami, K., Simidu, U., Taga, N. (1985). Microbial decomposition of phyto-and zooplankton in seawater. II. Changes in the bacterial community. Mar. Ecol. Prog. Ser. 21:7-13

Goldman, J. C., Caron, D. A. (1985). Experimental studies on an omnivorous microflagellate: implication for grazing and nutrient regeneration in the marine food chain. Deep Sea Res. 8: 899-915

Goldman, J. C., Caron, D. A., Andersen, O. K., Dennett, M. R. (1985). Nutrient cycling in a microflagellate food chain: I. Nitrogen dynamics. Mar. Ecol. Prog. Ser. 24: 231-242

Goldman, J. C., Caron, D. A., Dennett, M. R. (1987). Nutrient cycling in a microflagellate food chain: IV. Phytoplanktonmicroflagellate interactions. Mar Ecol. Prog. Ser 38: $75-87$

Hammer, K. H., Kattner, G. (1987). Dissolved free amino acids in the marine environment: a carbon to nitrogen ratio shift during diatom blooms. Mar. Ecol. Prog. Ser. 31: 35-45

Heinbokel, J. F. (1978). Studies on the functional role of tintinnids in the southern California Bight. I. Grazing and growth rates in laboratory cultures. Mar. Biol. 47: 177-189

Hobbie, J. E., Daley, R. J., Jasper, S. (1977). Use of Nuclepore filters for counting bacteria by fluorescence microscopy. Appl. environ. Microbiol. 33: 1225-1228

Jackson, G. A., Williams, P. M. (1985). Importance of dissolved organic nitrogen and phosphorus to biological nutrient cycling. Deep Sea Res. 32: 223-235

Lee, S., Fuhrman, J. A. (1987). Relationships between biovolume and biomass of naturally derived marine bacterioplankton. Appl. environ. Microbiol. 53: 1298-1303

Lancelot, C., Billen, G. (1984). Activity of heterotrophic bac-

This manuscript was presented by Dr A. Bianchi, Marseille, France teria and its coupling to primary production during the spring phytoplankton bloom in the Southern bight of the North Sea. Limnol. Oceanogr 29: 721-730

Moloney, G. L., Berg, M. O., Field, J. G., Newell, R. C. (1986). The effect of sedimentation and microbial nitrogen regeneration in a plankton community: a simulation investigation. J. Plankton Res. 8: 427-445

Mopper, K., Lindroth. P. (1982). Diel and depth variations in dissolved free amino acids and ammonium in the Baltic Sea determined by shipboard HPLC analysis. Limnol. Oceanogr. 27: 336-347

Newell, R. C., Moloney, C. L., Field, J. G., Lucas, M. I., Probyn, $T$ A. (1988). Nitrogen models at the community level: plant-animal-microbe interactions. In: Blackburn, $\mathrm{T} H$., Sorensen, J. (eds.) Nitrogen cycling in coastal marine environments. SCOPE 33, Wiley \& Sons, London, p. $379-414$

Oppenheimer, C. H., Zobell, C. E. (1952). The growth and viability of sixty-three species of marine bacteria as influenced by hydrostatic pressure. J. mar Res. 11: 10-18

Probyn, T. A. (1987). Ammonium regeneration by microplankton in an upwelling environment. Mar. Ecol. Prog. Ser. 37 : 53-64

Rault, P. L., Sohier, L. P., Rivier, A. M., Daumas, R. A. (1988). Dark bacterial-protozoan culture: acidification, nitrite accumulation, and protozoan inhibition in absence of phytoplankton. J. exp. mar. Biol. Ecol. 116: 273-291

Robinson, J. D., Mann, K. H., Novitsky, J. A. (1982). Conversion of the particulate fraction of seaweed detritus to bacterial biomass. Limnol. Oceanogr 27: 1072-1079

Sciandra, A. (1982). Etude d'un écosystème marin artificiel. Construction d'un modèle et application à l'exploitation d'une population de copépodes pélagiques Euterpina acutifrons (Dana). Thèse ßème cycle, Océanographie, Univ. Pierre et Marie Curie

Sohier, L., Bianchi, M. (1985). Development of a heterotrophic bacterial community within a closed prawn aquaculture system. Microb. Ecol. 11. 353-369

Strickland, J. D., Parsons, T. R. (1972). A practical handbook of sea water analysis. Bull. Fish. Res. Bd Can. 167: 1-311

Van Wambeke, F. (1988). Numération et taille des bactéries planctoniques au moyen de l'analyse d'images couplée à l'épifluorescence. Annls Inst. Pasteur/Microbiol. 139: $261-272$

Van Wambeke, F., Bianchi, M. A., Cahet, G. (1984). Shortterm bacterial reactivity of nitrogen enriched seawater of an eutrophic lagoon. Estuar coast. Shelf Sci. 19: 291-301

Van Wambeke, F., Bianchi, M. A (1985a). Dynamics of bacterial communities and qualitative evolution of heterotrophic bacteria during the growth and decomposition processes of phytoplankton in an experimental marine ecosystem. J. exp. mar. Biol. Ecol. 86: 119-137

Van Wambeke, F. Bianchi, M. A. (1985b). Bacterial biomass production and ammonium regeneration in Mediterranean sea water supplemented with amino acids. 2. Nitrogen flux through heterotrophic microplanktonic food chain. Mar. Ecol. Prog. Ser. 23: 117-128

Manuscript first received: July 1, 1989

Revised version accepted: February 14, 1990 